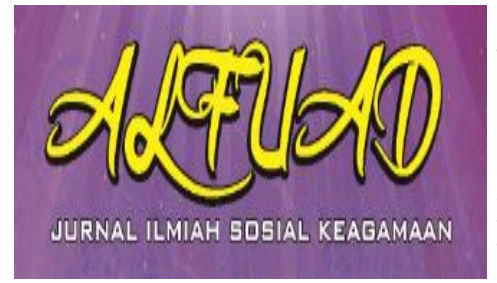

ALFUAD JOURNAL, 4 (1), 2020, (45-55)

(E-ISSN 2714-7606 P-ISSN 2614-4786 )

Available online at

http://ecampus.iainbatusangkar.ac.id/ojs/index.php/alfuad

\title{
EKSISTENSI LEMBAGA UNSUR ALIM ULAMA (PEMBERDAYAAN KEGIATAN KEAGAMAAN DI KENAGARIAN)
}

\section{Irwandi *)}

Institut Agama Islam Negeri Batusangkar, Indonesia

E-mail:

irwandi@iainbatusangkar.ac.id

\section{Novi Budiman}

Institut Agama Islam Negeri Batusangkar, Indonesia

E-mail:

novibudiman@iainbatusangkar.ac.id

*) Corresponding Author

\begin{abstract}
The role of the ulema is very important in the development of the spiritual field, because they are the heirs of the prophet, so that the position and function of the ulama for Muslims are those who are followed by their steps, character and deeds and their opinions and approvals can be taken. Alim Ulama in the nagari government system has the authority and responsibility for the growth and development of activities that refer to the aqeedah, sharia, worship and religious social relations of the people. as a social organization engaged in the religious field. The Alim Ulama Nagari Elemental Institution is part of the Indonesian Ulema Council (MUI) organization. . The analysis used in this study is the data analysis of interactive model data analysis techniques. The approach used is a qualitative approach. The informants in this research were Wali Nagari, Management of Element Institutions, and Society. From this study, it was concluded that the existence of Islamic religious scholars in Pasie Laweh was set out in the form of a work program with four main activities, including education activities, Da'wah activities, Activities of Ta'rul Masjid Fields, and Worship Facility Infrastructure Activities, in carrying out these activities. there are still official factors such as the lack of commitment of the management in improving the quality of religious activities.
\end{abstract}

Keywords: Existence, Alim Ulama, Nagari

\section{PENDAHULUAN}

Semenjak diberlakukannya otonomi daerah atau desentralisasi, daerah diberi hak, wewenang dan kewajiban untuk mengatur rumah tangganya sendiri sesuai dengan Undang-undang yang berlaku, menurut Piliang (2003), pada tingkat terendah otonomi berarti mengacu pada perwujudan free will yang melekat pada diri manusia sebagai anugrah paling berharga dari Tuhan. Free will inilah yang mendorong manusia untuk mengaktualisasikan diri dan menggali potensi terbaik dirinya secara maksimal. Pemberian hak, wewenang dan kewajiban tersebut pemerintah daerah merupaya untuk memberdayakan masyarakat sebagai potensi utama dalam implementasi otonomi daerah dimaksud, karena mulai dari perencanaan hingga pengawasan melibatkan partisipasi masyarakat. Pemberdayaan masyarakat dalam menurut Arbi Sanit (1998) dimaksudkan sebagai upaya mentranspormasikan segenap potensi 
pertumbuhan masyarakat, menjadi kekuatan nyata masyarakat, untuk melindungi dan memperjuangkan nilainilai dan kepentingan di dalam arena segenap aspek kehidupan. Karena itu pemberdayaan masyarakat perlu dikembangkan dalam rangka mewujudkan otonomi daerah yang lebih baik. Perwujudan otonomi ini harus berkaitan dengan pemberdayaan masyarakat dalam landasan, Kearifan lokal (local wisdom), Institusi dan Induvidu. Kearifan lokal (local wisdom), Institusi dan Induvidu dikebangkan untuk mewujudkan tujuan dari otonomi daerah secara baik, yaitu membangun partisipasi masyarakat dan mengundang keterlibatan publik seluasluasnya dalam proses perencanaan, implementasi dan evaluasi yang dijalankan, keterkaitan antara pemberdayaan masyarakat dan tujuan otonomi daerah berdampak kepada penyusunan regulasi tentang potensi yang ada disetiap daerah, salah satu potensi tersebut untuk daerah Sumatera Barat adalah mengembalikan fungsi pemeritahan yang selama ini di sebut pemerintahan desa beralih nama menjadi Pemerintahan Nagari. Hal ini sesuai Peraturan Daerah Propinsi Sumatera Barat No. 9 tahun 2000, tentang Ketentuan Pokok Pemeritahan Nagari dan Peraturan Daerah Kabupaten Tanah Datar Nomor 4 tahun 2008 tentang Nagari. Untuk mengatur dan menjalankan roda pemerintahan guna untuk kepentingan masyarakat, wali nagari di bantu oleh Badan Perwakilan Anak Nagari yang dipilih oleh masyarakata dan Badan Musyawarah Adat dan Syarak Nagari terdiri dari utusan Ninik Mamak, Alim Ulama, Cerdik Pandai, Bundo Kanduang dan komponen masyarakat lainnya yang tumbuh dan berkembang dalam Nagari. Kata 'ulama merupakan bentuk jamak dari kata tunggal (mufrad) alim yang berarti orang yang berilmu atau orang yang berpegetahuan. Kata ini berasal dari akar kata 'alima ya'lamu 'ilman (علم يعلم علما), bermakna suatu pengaruh/bekas atau kemuliaan yang membedakannya dengan yang lainnya, adapun Muhammad Ibn Mukrim Ibn Manzur al-Afriqikata mengatakan bahwa ulama dipahami sebagai orang yang memadukan pengetahuannya dengan pengalamannya.

Ulama' menurut Bahasa adalah orangorang yang mengetahui, sedangkan menurut istilah adalah orang yang mempunyai ilmu pengetahuan yang mendalam mengenai Alquran dan Sunnah serta mampu menerapkan nya dalam kehidupan sehari-hari. Dalam alquran surat Ali 'Imran ayat 18 menegaskan tentang kedudukan orang-orang yang berlimu;

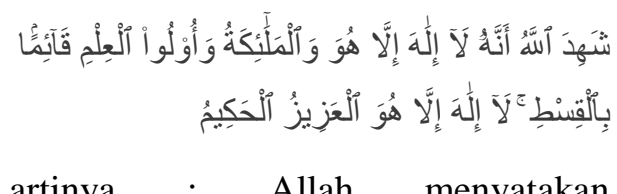
bahwasanya tidak ada Tuhan melainkan Dia (yang berhak disembah), Yang menegakkan keadilan. Para Malaikat dan orang-orang yang 
berilmu (juga menyatakan yang demikian itu). Tak ada Tuhan melainkan Dia (yang berhak disembah), Yang Maha Perkasa lagi Maha Bijaksana.

Berdasarkan hal tersebut peran ulama sangat penting karena mereka adalah pewaris nabi, sehingga kedudukan dan fungsi ulama bagi umat Islam adalah orang-orang yang diikuti langkah, sifat dan perbuatannya serta dapat diambil pendapat dan persetujuannya. Alim Ulama dalam sistem pemerintahan nagari memiliki wewenang dan tanggungjawab terhadap tumbuh dan berkembangnya kegiatan-kegiatan yang mengacu pada aqidah, syariah, ibadah dan hubungan-hubungan sosial keagamaan umat. sebagai organisasi kemasyarakatan yang bergerak di bidang keagamaan. Lembaga unsur Alim Ulama nagari merupakan bagian dari organisasi Majelis Ulama Indonesia (MUI).

Berdasarkan studi kepustakaan yang dilakukan, penelitian yang relevan dengan penelitian ini adalah, penelitian yang dilakukan oleh Nikmatin Tujuza (2018), dengan judul penelitian Peran Ulama Dan Umara Dalam Penguatan Aqidah Masyarakat(Studi Kasus Di Kecamatan Krueng Sabee Kabupaten Aceh Jaya), hasil penelitian ini mengungkapkan bahwa peran ulama dalam penguatan aqidah masyarakat Krueng Sabee sangat besar, dimana ulama berperan menjadi pemandu (mursyid) umat supaya masyarakat memiliki aqidah yang benar dengan ahlusshunnah wal jamaah, ulama juga berperan sebagai pilar kehidupan masyarakat, ulama juga menjaga kemurnian dan kesucian aqidah masyarakat, ulama juga berperan meningkatkan moralitas dan menekan angka penyakit sosial masyarakat, serta ulama menjadi wadah pemersatu umat. Selain itu, peran umara (pemimpin) dalam penguatan aqidah masyarakat Krueng Sabee juga sangat besar,dimana melalui kegiatan yang di lakukan seperti pengajian tauhid tasawuf, ratebsiribee, penguatan pada TPA, pemberian insentif kepada imum masjid melalui Dinas Syariat, umara dapat berperan meningkatkan kesadaran umat dan meningkatkan pengetahuan umat serta yang terpenting menguatkan aqidah masyarakat terhadap iman kepada Allah. Peluang dan tantangan yang dirasakan dalam menguatkan aqidah masyarakat sebenarnya tidak begitu signifikan, peluang yang dirasakan selama ini bahwa masyarakat sangat mendukung kegiatan yang dilakukan oleh ulama dan umara, dengan ikut serta setiap kegiatan dan masyarakat sangat antusian dengan kegiatan keagamaan tersebut, dengan begitu memudahkan ulama dan umara untuk melakukan kegiatan keagamaan, sedangkan kendala yang dirasakan pun tidak begitu berpengaruh, hanya saja masyarakat kurang tertarik dengan kegiatan keagamaan dan sibuk dengan urusan duniawi, sibuk dengan rutinitas yang sifatnya kepentingan kehidupan, sehingga meninggalkan pengajian yang akibatnya masyarakat tidak tekun beribadah, bahkan malas melakukannya, banyak yang mengeluh dengan kehidupan dan takut dengan mushibah, sehingga ini menjadi kebiasaan yang tidak baik bagi kehidupan masyarakat itu sendir.

Penelitiam yang pernah dilaksanakan

oleh Ahdi Makmur (2015) dalam bukunnya 
berjudul Ulama dan Pembangunan Sosial yang mengatakan bahwa, ulama adalah juga modal sosial. Di-katakan modal sosial karena ulama memiliki nilai surplus yang diperoleh oleh masyarakat sebagai pemilik modal atau kapital setelah diinvestasikan misalnya dalam lembaga pendidikan Islam formal, baik (pondok)pesantren atau madrasah(diniyah), dan non-formal di masyarakat dalam bentuk majlis ta'lim dan atau pengajian agama. Sebagai produk dari dua bentuk lembaga pendidikan Islam tersebut, ulama kemudian menghasilkan peserta didik atau pengikut majlis ta'lim yang religius dan berperilaku terpuji. Dari mereka ini selanjutnya masyarakat mendapat kan manfaat kembali. Dengan kata lain, ulama sebagai modal atau kapital sosial telah melahirkan anggota atau sekelompok masyarakat (yaitu sebagai produk dari lembaga pendidikandan dakwah di mana ulama ikut ambil bagian di dalamnya) yang memiliki nilai guna atau surplus (yaitu anggota masyarakat yang berilmu dan berakhlak). Nilai guna tersebut kemudian dapat dinikmati kembali oleh warga masyarakat lainnya.

Penelitian ini juga mengkaji tentang Peran Ulama dalam pembangunan, namun focus kajian penulis berbeda dengan penelitian sebelumnya, pada penelitian ini di fokuskan pada aspek eksistensi lembaga unsur alim ulama (Pemberdayaan Kegiatan Keagamaan Di Kenagarian Pasie Laweh Kecamatan Sungai Tarab Kabupaten Tanah Datar)

\section{METODE}

$$
\text { Metode yang digunakan dalam }
$$
melihat Eksistensi lembaga unsur Alim ulama di Kenagarian Pasie Laweh dengan menggunakan metode Penelitian Kualitatif. metode pengumpulan data dilaksanakan dengan wawancara, obesrvasi studi dokumentasi dengan proses pengumpulan data, analisis data berpedoman kepada teknik analisis data model interaktif menurut Miles \& Huberman yaitu; pengumpulan data, reduksi data, display data dan tahapan penarikan kesimpulan atau tahap verifikasi.

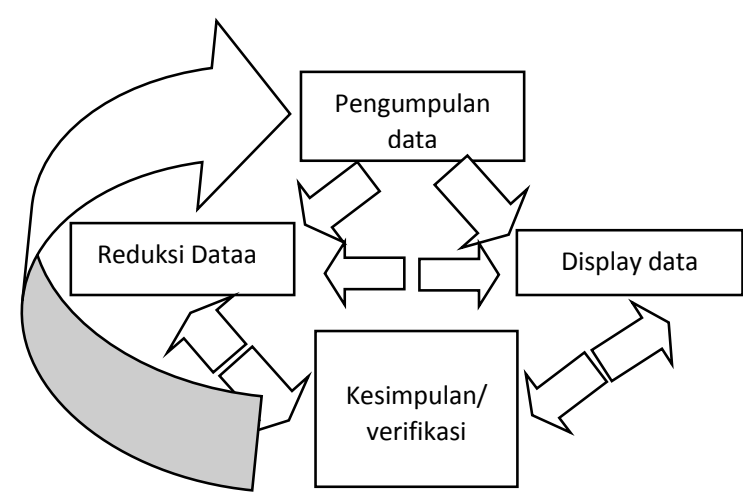

Model Interaktif Miles dan Huberman

Menurut Denzin dan Lincoln dalam Haris (2012) Penelitian ini Kualitatif ditujukan untuk mencapai pemahaman mendalam mengenai organisasi dan peristiwa khusus daripada mendeskripsikan bagian permukaan dari sampel besar dari sebuah populasi. Dan penelitian kualitatif ditujukan untuk mendapatkan pemahaman yang mendasar melalui pengalaman first-hand dari peneliti yang langsung berproses dan melebur menjadi satu bagian yang tidak terpisahkan dengan subjek dan latar yang akan diteliti berupa laporan yang sebenar-benarnya, apa adanya dan catatan-catatan lapangan yang aktual. 
Informan pada penelitian ini adalah pengurus lembaga Unsur Alim Ulama, Wali Nagari, dan masyrakat.

\section{HASIL DAN PEMBAHASAN}

\section{Peran dan fungsi alim ulama di Sumatera Barat}

Minangkabau (nagari adat), Sumatera Barat (sebagai sebuah sistem Pemerintahan ) sebagai bagian dari budaya yang memegang filosofi “adat Basandi Syarak-Syarak Basandi Kitabullah" menempatkan ulama pada posisi sentral dalam pembangunan, terutama pembangunan bidang Agama dan Kemasyarakatan, Filosofi Minangkabau yang mengedepankan Kitab Suci Al-quran sebagai pondasi kehidupan tentu tetap terjaga melalui ilmu yang di miliki. Kuatnya kedudukan alim ulama di Minangkabau tidak akan terlepas dari bagaimana Islam berkembang mulai dari masuknya Islam, eksistensi ulama-ulama dan pengaruhnya ke Nusantara, kedudukan dan eksistensi raja-raja Pagaruyung yang beragama Islam dalam mengembangkan Islam, serta peran tokoh-tokoh nasional yang berlatar belakang pendidikan keislaman yang kuat untuk membangun Indonesia. Begitu banyaknya peran dan fungsi ulama di Minangkabau sehingga dalam pemerintahan di Minangkabau kedudukan ulama di katakan dalam pepatah Minangkabau dengan: "Tigo Tungku Sajarangan, Tali Tigo nan Sapilin" yang terdiri dari Alim Ulama (orang yang memiliki ilmu agama yang tinggi), Cadiak Pandai (golongan terpelajar) dan Niniak Mamak (para pemimpin suku dalam sebuah nagari). Alim ulama disebut suluah bendang dalam nagari, artinya alim ulama berfungsi sebagai penerang kehidupan di masyarakat yang bertugas mengurus persoalan ibadah masyarakat dalam nagari, mengelola lembaga pendidikan di rumah-rumah ibadah, seperti masjid, surau atau mushalla, karena itu alim ulama sangat berpengaruh kepada ketinggian ilmu dan kedalaman budi pekerti

Peran dan fungsi alim ulama di Sumatera Barat menduduki posisi yang sangat strategis, karena alim ulama di pandang sebagai orang yang mampu memberikan ketenangan lahir dan batin atau suluh bendang dalam nagari yang di dalam nya ada sifat keteladanan, yang bisa menunjukkan Dan menyatakan melaksanakan amar ma'ruf dan nahi mungkar artinya fungsi dan kedudukan ulama di Minang memberi dapat memberikan fatwa dan sekaligus sebagai wadah utama bagi pemerintahan propinsi untuk mengeluarkan regulasi-regulasi yang berhubungan khususnya dibidang sosial keagamaan. Yulizal Yunus Dt. Rajo Bagindo (2009) mengatakan Kedudukan alim ulama dihormati kerena ilmu dan keteladanan imannya. seseorang ulama dalam masyarakat adalah karena ilmu yang dituntutnya dan ia menduduki jabatan ulama karena kemampuan pribadinya, ketaatan dengan kesungguhannya. Jabatan ini tidak dapat diturunkan, Walaupun seseorang itu mempunyai ilmu yang tinggi dalam bidang agama tapi tidak mampu menyebarkannya lewat tabligh-tabligh dan 
belum diakui kepemimpinannya sebagai ulama oleh masyarakat belumlah boleh disebut ulama dan Fungsi alim ulama dalam masyarakat adalah pengikat tali lahir batin dan memberi contoh dan teladan/ panutan dan sebagai suluh bendang dalam nagari. Ulama itu berkewajiban menunjukkan yang baik dan yang buruk, menyatakan yang terlarang (nahi) dan tersuruh (amar) oleh agama Islam.

\section{Kebijakan Pemerintahan Nagari Pasie Laweh Bidang Keagamaan}

LeoAgustino (2008:7) mendefinisikan kebijakan sebagai serangkaian tindakan/kegiatan yang diusulkan seseorang, kelompok, atau pemerintah dalam suatu lingkungan tertentu di mana terdapat hambatan-hambatan (kesulitan-Kesulitan) dan kesempatan kesempatanterhadap Pelaksanaan usulan kebijaksanaan Tersebut dalam rangka mencapai tujuan tertentu.Sesuai Rencana Pembangunan Jangka Menengah (RPJM) Nagari Pasie laweh yang di dasari oleh visi dan misi, maka visi Pemerintahan Nagari Pasie laweh yaitu ; "Membangun Nagari Pasie Laweh Yang Memiliki Budaya Dan Masyarakat Sejahtera Di Bawah Kendali Iman Dan Taqwa, Terwujudnya Adat Basandi Syara'-Syara' Basandi Kitabullah", dengan misi: (a) Membuka Akses Komunikasi dan informasi online 24 jam melalui handpone dengan nomor kartu resmi pemerintah nagari, agar berfungsi memberi dan menerima, berita dan pesan dari masyarakat sekretariat nagari untuk masyarakat yang berdomisili dalam kenegarian pasie laweh. Menyelenggarakan pemerintahan nigari yang transparan, memperoleh informasi yang dibutuhkan dan bebas menyampaikan pendapat dan saran ke pemerintahan nigari (c) Menjaga dan meningkatkan pembangunan sarana dan prasarana nigari seperti, jalan, balai lapangan olahraga, masjid, mushala, surau serta sarana listrik dan air bersih di nagari (c) Menjaga fasilitas umum nigari seperti jalan, balai, lapangan olahraga, masjid, mushalla, surau tetapi layak dipergunkan masyarakat dan melakukan perbaikan. (d) Secara rutin melakukan kegiatan yang melibatkan seluruh elemen masyarakat seperti gotong royong, kgiatan olahraga, kegiatan PKK, kegiatan majeleis ta'lim dan pengajian, penyuluhan kesehatan, penyuluhan pertanian dan lain-lain. (e) Bekerjasama dengan sekolah-sekolah maupun TPA/TPSA pengajian, untuk biasa mendidik generasi muda sehingga menghasilkan generasi muda berakhlak beriaman dan bertaqwa, serta pengetahuan ilmu dan berguna. (f) Bekerjasama dengan segal unsur yang ada dalam nigari maupun memanfaatkan potensi perantau.

Bertitik tolak dari Visi dan Misi Diatas maka Pemerintahan Nagari Pasie Laweh fokus pada pembangunan yang di arahkan kepada: (1) Pembangunan Agama 
dan Budaya. (2) Pembangunan hukum dan Pemerintahan. (3) Pembangunan ekonomi. (4) Pembangunan Sumber daya Alam dan lingkungan. (5) Pembangunan sumber daya manusia. (6) Pembangunan sarana dan prasarana

Arah kebijakan pembangunan yang programkan oleh Pemerintah Nagari, memperlihatkan bahwa program kegiatan keagamaan merupakan program pertama yang harus dilaksanakan, sebelum program lainnya., sehingga peran serta unsur alim ulama di nagari sangat di harapkan.

\section{Eksistensi Lembaga Unsur Alim Ulama dalam Pembangunan di Nagari Pasie Laweh}

Eksistensi dalam dalam Kamus Besar Bahasa Indonesia secara Bahasa mengandung arti "keberadaan", sedangkan secara istilah menurut Abidin Zaenal (2007:16) adalah: suatu proses yang dinamis, suatu, menjadi atau mengada. Ini sesuai dengan asal kata eksistensi itu sendiri, yakni exsistere, yang artinya keluar dari, melampaui atau mengatasi. Jadi eksistensi tidak bersifat kaku dan terhenti, melainkan lentur atau kenyal dan mengalami perkembangan atau sebaliknya kemunduran, tergantung pada kemampuan dalam mengaktualisasikan potensi-potensinya".

Eksisitensi lembaga unsur alim ulama di nagari Pasie Laweh dimulai dengan struktur kepengurusan sebagai berikut:

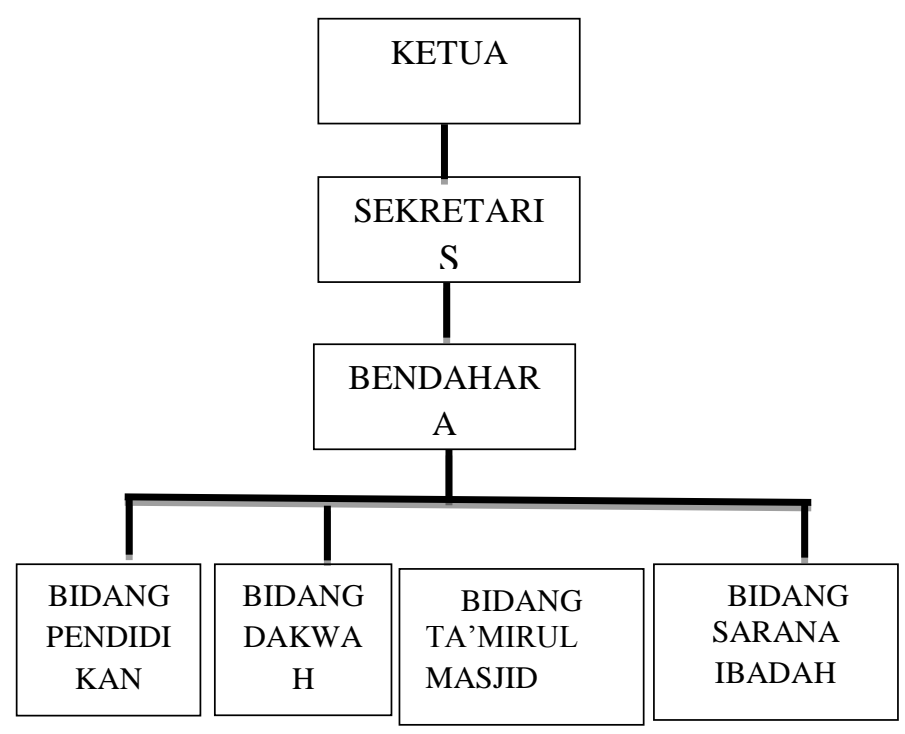

Pelaksanaan kegiatan ini menurut Ketua lembaga Unsur alim ulama melaibatkan seluruh unsur terutama unsur generasi muda sebagai generasi penerus kegiatan keagamaan. Dalam melaksanakan kegiatan keagamaan pengurus Lembaga alim ulama selalu melaksanakan koordinasi, konsultasi dan komunikasi yang efektif dengan berbagai pihak sehingga kegiatan yang dilaksanakanv efektif sesuai dengan program yang dilaksanakan. Ekosusilo dan Kasihadi (1993) dalam candra dan M. Rifa'i menyatakan bahwa keefektifan adalah suatu keadaan yang menunjukkan sejauh mana apa yang telah direncanakan dapat tercapai. Semakin banyak rencana yang dapat tercapai, maka semakin efektif pula kegiatan tersebut. pelaksanaan program kerja yang di laksanakan diantaranya, a). bidang pendidikan, Menurut John Dewey sebagaimana dikutip oleh Mahfud Junaedi 
dalam bukunya Kiai Bisri Musthafa Pendidikan Keluarga Berbasis Pesantren, (2009: 7) pendidikan merupakan kebutuhan hidup asasi (anecessity of life), fungsi sosial (social function), pengarah, pengendali dan pembimbing (direction control and guidance), konservatif (mewariskan dan mempertahankan cita-cita suatu kelompok), dan progressive (membekali dan mengembangkan pengetahuan nilai dan ketrampilan sehingga mampu menghadapi tantangan hidup). Begitu pentingnya pendidikan bagi manusia dan tugas berat lembaga unsur alim ulama dalam memanusiakan kemanusian manusia, maka langkah yang diambil adalah mendirikan rumah tahfiz dan pelatihan bagi guru-guru Taman Pendidikan Al-quran. Pelaksanaan penguatan lembaga pendidikan ini bekerja sama dengan pihak nagari. kerjasama dimaksud dalam bentuk bantuan keuangan, bantuan keuangan ini diambil dari dana Anggaran Pendapatan dan Belanja Nagari yang di anggarkan setiap tahunnya. Manfaat dari pelatihan ini adalah meningkatnya kemampuan guru TPA dalam bidang pendidikan dan pembelajaran Al-Quran. Pelaksanaan kegiatan rumah tahfiz dan pelatihan bagi guru TPA murupakan salah satu bentuk aplikasi dari Peraturang Daerah Kabupaten Tanah Nomor 2 tahun 2007, dalam melaksanakan kegiatan pedidikan bidang keagamaan baik pelatihan guru TPA, dan pelatihan imam, khatib dan bilal dilaksanakan satu kali dalam setahun dengan pendanaan berasal dari anggaran belanja nagari, b). dibidang dakwah, menurut Syaikh Ali Mahfudz dalam Salmadanis (2003), pengertian Dakwah adalah mengajak manusia (mad'u) untuk mengerjakan kebaikan dan mengikuti petunjuk, menyuruh mad'u berbuat baik dan melarang mereka untuk berbuat jelek agar mereka mendapat kebahagian dunia dan akhirat. adalah telah dilaksanakan, beberapa kegiatan diantaranya menfasilitasi kegiatan pengajian rutin bulanan baik yang di laksanakan oleh remaja masjid, majlis ta'lim dan pengurus masjid dengan agenda utama adalah pengkajian bidang aqidah, syariah, ibadah dan muamalah yang dilaksanakan setiap minggu, bulanan dan tahunan (peringatan hari besar Islam). Dalam kajian tersebut juga di laksanakan sosialisasi berkenaan dengan hal-hal yang berkaitan dengan fatwa-fatwa MUI dan pencegahan terhadap permutadan dan ajaran yang menyimpang. Pelaksanaan kegiatan bidang dakwah. Lembaga unsur alim ulama di tempatkan sebagai fasilitator kegiatan, dan sekaligus sebagai inspirator untuk seluruh kegiatankegiatan dakwah. c). Takmirul Masjid, masjid merupakan pusat kegiatan umat baik dibidang ekonomi, pendidikan, sosial, budaya dan lain sebagainya, sebagaimana yang telah di contohkan oleh rasulullah SAW, karena itu anak nagari di Minangkabau bertanggungjawab dalam 
mentakmirkan masjid, hal ini sesuai dengan Surat At-taubah ayat 18:

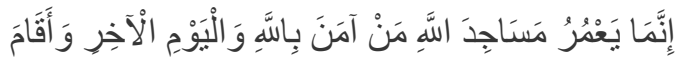

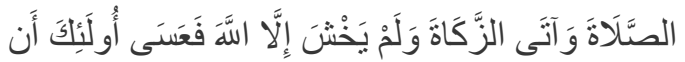

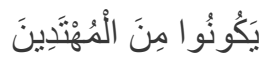

Artinya: hanya yang memakmurkan masjid-masjid Allah ialah orang-orang yang beriman kepada Allah dan hari kemudian, serta tetap mendirikan sholat, menunaikan zakat dan tindak takut (kepada siapapun) selain kepada Allah, maka merekalah orang-orang yang diharapkan termasuk golongan orangorang yang mendapat petunjut (Attaubah:18)

dalam menyikapi hal tersebut lembaga unsur alim ulama Pasie Laweh menjadikan masjid sebagai pusat kegiatan seperti pelayanan dan pendistribusian zakat, pelayanan terhadap masalahmasalah sosial dan lain sebagainya sehingga ta'mir masjid adalah pelayanan jamaah, bukan ditempatkan sebagai penguasa, prinsip utama dari seorang ta'mir masjid adalah bagaimana umat bisa menjadikan masjid sebagai pusat kegiatan sehingga menjadikan masjid berfungsi sebagaimana yang di harapkan. d). Sarana Ibadah, pemeliharaan sarana ibadah merupakan salah satu tugas utama dari ta'mir masjid, untuk mewujudkan masjid yang bersih, aman dan tentram lembaga unsur alim ulama beserta pengurus masjid berusaha memperbaiki kerusakankerusakan dengan mengumpulkan dana dari masyarakat, para perantau dan para donator dan menfasilatasi bantuan dari pemerintah daerah.

Pelaksanaan program yang telah direncanakan oleh lembaga unsur Alim Ulama Nagari Pasie Laweh, telah berjalan sesuai dengan program tahunan yang diencanakan, dalam melaksanakan kegiatan dimaksud ada beberapa hal yang menjadi faktor penghambat dalam melaksanakan program dimaksud, seperti yang di ungkapkan oleh ketua unsur alim ulama Pasie Laweh, diantara faktor penghambat tersebut adalah, masih kurangnya komitmen dari para pengurus untuk menjalankan seluruh program yang telah direncanakan, sehingga berdampak terhadap kualitas pelaksanaan kegiatan bidang keagaamaan di Nagari Pasie Laweh, dengan gambaran program kegiatan, pelaksanaan dan faktor-faktor penghambat dan penunjang sebagai berikut:

\section{KESIMPULAN DAN SARAN}

Peran dan fungsi lembaga unsur alim ulama di Nagari Pasie Laweh menempati posisi yang strategis, terutama dalam memelihara kelangsungan kegiatan bidang keagamaan, sekaligus sebagai wadah dalam menjaga Aqidah umat agar tidak terpengaruh dari unsur-unsur kemurtadan, disamping sebagai wadah untuk menjaga Aqidah umat, Unsur alim ulama juga mempunyai tugas diantaranya, 
menjaga kelangsungan syariah islam sesuai dengan Al-quran dan Sunnah.

Tugas dan fungsi lembaga unsur alim ulama dimaksud tidak akan berjalan sesuai dengan yang diharapkan apabila tidak ada dukungan penuh dari pemerintah Nagari Pasie Laweh, dukungan dimaksud dalam bentuk dukungan moril maupun materi, sehingga percepatan keberhasilan pembangunan bidang keagamaan yang menjadi Misi Pemerintah Nagari Pasie Laweh dapat terwujud. Untuk meningkatkan peran dan fungsi lembaga unsur alim ulama di nagari Pasie Laweh dan sekaligus untuk melanjutkan tradisi kegiatan keagamaan di Pasie Laweh yang semenjak dahulu berkembang dengan baik, diharapkan pengurus Lembaga Unsur Alim Ulama dan Pemerintah Nagari sudah dapat memprogramkan: a). mendorong kaum yang ada di nagari untuk kembali meneksistensikan keberadaan urang jinih nan ampek sebagai bentuk peran serta kaum dalam pembangunan bidang keagamaan, diantara urang jinih nan ampek dimaksud adalah; imam, khatib, bilal dan angku, b). beasiswa pendidikan khusus bagi generasi muda yang berkeinginan kuat untuk mempelajari Agama di tempat-tempat/lembaga-lembaga pendidikan formal yang melahirkan kaderkader ulama seperti beasiswa bagi generasi muda yang melanjutkan pendidikan di pondok-pondok pesantren serta generasi muda yang ingin melanjutkan pendidikan keagamaan di Perguruan tinggi baik dalam maupun di luar negeri, bukankah dulu ada tradisi dari beberapa suku di Minangkabau termasuk di Nagari Pasie Laweh yang menyiapkan kadernya untuk menjadi imam, khatik, bilal dan khadih, melalui lembaga pendidkan pondok pesantren.

\section{DAFTAR PUSTAKA}

Al-qur'an terjemahan. (2009) CV Diponegoro,.

Makmur, A. (2015). Ulama dan Pembangunan Sosial. Yogyakarta: Aswaja Pressindo.

Karni, A. dkk (2017). Pergeseran Peran dan Fungsi UJ4 di Minangkabau. Pusat Penelitian LP2M UIN Imam Bonjol Padang,

Candra, \& Rifa'I, M. (2016), Dasar-Dasar Manajemen. Medan: Perdana Publishing.

Chalid, P. (2005). Otonomi Daerah masalah, pemberdayaan dan konflik. Jakarta: Kemitraan

Haris, H. (2010). Metode Penelitian Kualitatif Untuk Ilmu-Ilmu Sosial. Jakarta: Salemba Humanika.

Kertya Witaradya, http://kertyawitaradya.wordpress.co m/2010/01/26/tinjauan- eoritismplementasi-kebijakan-publikl diakses tanggal 12 Maret 2020

Kamus Besar Bahasa Indonesia; https://kbbi.web.id/eksistensi/akses 12 Maret 2020

Junaedi, M. (2009). Kiai Bisri Musthafa, Pendidikan Keluarga Berbasis Pesantren, Semarang: Walisongo Press.

Muhammad Ibn Mukrim Ibn Manzur alAfriqi, Lisan al-,,Arab (Cet. I; Bairut: Daar Sadir, t. th.). Jilid 12 h. 416 
Irwandi, Novi Budiman: Eksistensi Lembaga Unsur Alim Ulama (Pemberdayaan Kegiatan ...

Tujiza, N. (2018). Peran Ulama Dan Umara Dalam Penguatan Aqidah Masyarakat (Studi Kasus Kecamatan Krueng Sabee Kabupaten Aceh Jaya), Skripsi tidak diterbitkan, Fakultas Ushuluddin Dan Filsafat Universitas Islam Negeri Ar-Raniry Banda Aceh.

Piliang, I. J. dkk (ed) (2003). Otonomi daerah, evaluasi dan proyeksi, Jakarta, Yayasan harkat bangsa bekerjasama dengan partnership governace reform in indonesia

Salmadanis. (2003) Filsafat Dakwah, Jakarta: Surau.
Arbi, S. (1998). Reformasi Politik. Yokyakarta: Pustaka Pelajar.

Taufiqurakhman. (2014). Kebijakan Publik. Jakarta: Fakultas Ilmu Sosial dan Ilmu Politik Universitas Moestopo.

Yunus, Y. Dt. Rajo Bagindo. (2009). Sitem Kepemimpinan Minangkabau, https://wawasanislam.wordpress.co $\underline{\mathrm{m} / 2009 / 03 / 06 / \text { sistim- }}$

kepemimpinan-minangkabau/akses 